\section{Acute respiratory infections control in the context of the IMCl strategy in the Americas}

\section{Controle das infecções respiratórias agudas no contexto da estrategia AIDPI nas Américas}

Yehuda Benguigui 1

1 Regional Advisor in Integrated Management of Childhood Illness (IMCI)). Pan-American Health Organization and World Health Organization 525 Twenty-third Street, N.W, Washington, DC 20037, USA

\begin{abstract}
As infecções respiratórias agudas (IRA) são importante causa de morbidade e mortalidade em menores de cinco anos. Importantes contrastes são observados em relação a isto nos diferentes países das Américas, e também entre regiões ou estados de um mesmo país. A morbidade está associdada a vários fatores, especialmente com a situação nutricional das pacientes e o tempo de aleitamento materno. Também as características dos cuidados prestados a essas crianças durante a doença são essenciais, com destaque para a percepção dos pais ou responsáveis em relação à doença, os cuidados que os mesmos prestam à criança durante a doença, a preocupação em decidir e consultar os serviços de saúde, a forma em que esses cuidados são oferecidos pelos serviços de saúde e em que as orientações são cumpridas em casa. Especial preocupação deve existir em relação à resistência bacteriana aos antibióticos, sendo um problema crescente na América, com uma média de $26,1 \%$ de resistência do Streptococcus pneumoniae à penicilina. Os antibióticos são freqüentemente utilizados de forma irresponsável com $70 \%$ das crianças com IRA recebendo-os desnecessariamente. Controlar as IRA tem-se tornado prioridade. Intervenções preventivas como as atuais vacinas conjugadas para Haemophilus influenzae e Streptococcus pneumoniae, e o manejo padronizado de casos, como proposto pela estrategia Atenção Integrada a Doenças Prevalentes na Infância (AIDPI), aparecem como os mais importantes passos para este problema de Saúde Pública.
\end{abstract}

Key words Infecções respiratórias, Cuidado da criança, Educação em saúde, Serviços de saúde
Resumo Acute respiratory infections (ARI) are an important cause of morbidiyty and mortality in children all over the World, particularly in developing countries. Contrasts in mortality can be observed among the countries in America, and also within the countries. Contrasts are also observed in morbidity, associated with differences in nutritional status, absence of breast-feeding and characteristics of care given for ill chidren. Parents perception of disease, patterns and habits of care administered to child during the illness, level of concern about decision to seek assistence, manner in wich care is sought and extent to wich recommendations are followed have great influence in the course and outcome of the disease. Bacterial resistance to antibiotics is an increasing problem in America, with an average of $26,1 \%$ resistance of Streptococcus pneumonia to penicilin. Antibiotics are frequently used in irrational way, and up to $70 \%$ of ARI receive antibiotics unnecessarily. Controlling IRA has become a priority. Preventive interventions with vaccines, specially current conjugate vaccines against Haemophilus influenzae and Streptococcus pneumoniae, and standardized case management, as proposed by Integrated Management of Childhood Ilness (IMCI) seems to be the most important steps for this public health problem.

Palavras-chave Respiratory tract infections, Child care, Health education, Health services 


\section{Introduction}

Since the 1960s, acute respiratory infections (ARI) have been one of the most serious public health problems for young children, as these illnesses have consistently been among the five leading causes of death in children under five. ${ }^{1}$ Although by the end of the 20th century child mortality from ARI had declined, thousands of boys and girls continue to die each year from these diseases, and many more suffer periodic episodes. ${ }^{2}$ Acute respiratory infections remain a serious health problem for children in most countries of the world - particularly in developing countries, where mortality and severe morbidity indices are considerably higher in the developed countries.

The proportion of child mortality and morbidity attributable to ARI is not the only reason why these infections constitute a major public health problem. Given the frequency of these illnesses in children under five, the care that must be provided for them imposes a significant burden on parents and health services in terms of time and money. ${ }^{3}$ In addition, the care provided by the family and the health services is not always the most efficient way to treat these illnesses. Improper care often leads to complications and additional problems, such as those associated with the excessive and improper use of antibiotics, which is one of the main reasons for the recent rise in bacterial resistance to these drugs. ${ }^{4}$

Under the framework employed in recent decades, implementing programs for the prevention and control ARI was a priority. These programs promoted first, the development of specific strategies 5 and then, integrated strategies, 6 all aimed at preventing respiratory infections, reducing their duration and the probability that they might worsen, and preventing mortality. Together with these objectives, control strategies were proposed as a tool for standardizing diagnostic and treatment criteria to improve the quality of care administered to children in the health services and in communities. ${ }^{7}$

\section{ARI as a cause of infant mortality}

Although mortality from ARI has declined in recent decades, at the end of the $20^{\text {th }}$ century these infections continued to account for some $5 \%$ to $10 \%$ of deaths in children under five in the Western Hemisphere. ${ }^{2}$ However, the situation varied from country to country. While ARI were responsible for around $3 \%$ of under five mortality in Canada and the United States, in countries such as Ecuador and Peru the proportion of ARI-related deaths in this age group was around $20 \%$.

The estimated risk of death from respiratory illnesses during the first five years of life in 1999 was 344,3 per 100.000 population in Guatemala, and as low as four per 100.000 population in Canada. Children under five in Guatemala, therefore, had a relative risk of 86,1 compared to children in that age group in Canada. This reveals the large contrasts in early childhood mortality from respiratory illnesses among the countries of the Region.

These contrasts can also be observed within the countries by disaggregating mortality figures by states, provinces, departments, or other administrative divisions. 8

An analysis of mortality from pneumonia and influenza in Peruvian children under five in 2000 showed that the relative risk of dying from these causes during the first five years of life was more than seven times higher in some departments than in the departments with lower mortality rates. The differences were even more marked in a similar study conducted in Argentina. Children under five in the province with the highest mortality from respiratory illnesses had a relative risk of dying from these causes 11 times higher than for children who lived in the province with the lowest mortality.

These differences, which show the contrast between and within countries, are also seen in historical trends. Although in recent years mortality from respiratory illnesses has declined overall in the Region of the Americas and within the majority of the countries, the rate of this decline has varied (Table 1). The differences between countries are also replicated when trends are analyzed within the countries themselves. Comparing provinces, states, or departments, the rate of decline has been several times slower in some than in others. 8 
Comparison of the average annual percentage decline in mortality from pneumonia and influenza in children under five, in selected countries of the Americas, 1980-1990 and 1990-2000.

\begin{tabular}{|c|c|c|c|c|c|}
\hline \multirow[b]{2}{*}{ Country } & \multicolumn{3}{|c|}{ 1980-1990 } & \multicolumn{2}{|c|}{$1990-2000$} \\
\hline & $\begin{array}{l}\text { Rate at the } \\
\text { beginning of } \\
\text { the decade }\end{array}$ & $\begin{array}{c}\text { Annual decline } \\
\text { during the } \\
\text { decade }\end{array}$ & $\begin{array}{l}\text { Rate at the } \\
\text { beginning of } \\
\text { the decade }\end{array}$ & $\begin{array}{c}\text { Annual decline } \\
\text { during the } \\
\text { decade }\end{array}$ & $\begin{array}{c}\text { Rate at the } \\
\text { end of the } \\
\text { decade }\end{array}$ \\
\hline Brazil & 131,9 & 7,1 & 58,1 & 7,8 & 26,5 \\
\hline Canada * & 7,8 & 10,2 & 2,9 & 4,2 & 1,9 \\
\hline Cuba & 37,9 & 5,9 & 22,4 & 9,1 & 8,7 \\
\hline Ecuador & 182,4 & 7,9 & 86,4 & 5,1 & 58,2 \\
\hline United States ** & 7,8 & 5,8 & 4,2 & 5,3 & 2,4 \\
\hline Mexico & 235,7 & 7,6 & 111,4 & 11,6 & 27,5 \\
\hline Panama & 48,8 & 6,3 & 23,4 & $-2,3$ & 27,4 \\
\hline Paraguay & 108,9 & 6,1 & 53,9 & 2,2 & 34,8 \\
\hline Uruguay & 37,8 & 2,8 & 33,7 & 6,8 & 17,0 \\
\hline Venezuela & 61,1 & 6,1 & 49,1 & 6,0 & 24,0 \\
\hline
\end{tabular}

* Mortality figures for Canada for 2000 were not available, so the average annual percentage decline corresponds to 1979-1989 and 19891999. The year 1987 is omitted from the 1979-1989 period because figures for that year were not available; ${ }^{* *}$ Mortality figures for the United States for 2000 were not available, so the average annual percentage decline corresponds to $1979-1989$ and $1989-1999 ; * \star * ~ T h e$ average annual percent decline for Nicaragua for 1980-1990 was calculated for the period from 1983-1990 because the figures were not available from 1980 to 1982.

Note: The average annual percentage decline was calculated by linear regression of the logarithm with base 10 of annual mortality rates, using the least squares method.

Source: IMCI (Integrated Management of Childhood Illness) Regional Unit. Program on Communicable Diseases (HCT), Division of Disease Prevention and Control (HCP). Based on vital statistics information from the Ministries of Health of each country. PAHO (Pan American Health Organization); 2002.

As a result of these different rates of decline in countries and their administrative divisions, the gap between areas has increased. The relative risk of dying from respiratory illnesses is several times higher for children under five in certain regions than for those in others.

Table 1 shows the trend in mortality from pneumonia and influenza, which were the leading causes of death from respiratory illnesses in children under five for selected countries in the Hemisphere during the last two decades of the $20^{\text {th }}$ century. From 1980 to 1990 , the fastest rate of decline was in Canada, where annual mortality fell by $10,2 \%$ throughout the period. The rate of decline in Nicaragua and Uruguay, in contrast, was less than half that figure. As a result of this difference in the rate of decline, the relative risk of dying from pneumonia and influenza during the first five years of life - which was
4,8 for Uruguay and 10,4 for Nicaragua versus that of Canada at the start of the 1980s - had more than doubled $(11,6)$ in Uruguay and tripled $(36,5)$ in Nicaragua by the end of the decade.

The situation changed in the following decade. While the rate of decline in mortality from pneumonia and influenza in children under five was cut by more than half in Canada $(4,2 \%$ annually versus $10,2 \%$ in the previous decade), the rates of decline in Nicaragua and Uruguay were more than double those of the previous decade, with annual rates of $10,3 \%$ and $6,8 \%$, respectively. As a result, the relative risk of dying from these illnesses during the first five years of life in 2000, compared to the end of the previous decade, was reduced to 8,9 for Uruguay and to less than half, 14,2, for Nicaragua.

Comparing the rate of decline in mortality from pneumonia and influenza between countries is also 
important for verifying the existing potential to reduce the differences. Table 1 shows that Canada was able to reduce its mortality from pneumonia and influenza in children under five at a rate of $10 \%$ annually over a decade, starting from a mortality of 7,8 per 100.000 population. This figure is far below the rates recorded in other countries at the beginning of the 1990s; notwithstanding, the rates of decline in many of these countries were under $10 \%$ annually and in some, less than half.

\section{ARI as a cause of morbidity}

The proportion of early childhood deaths attributable to respiratory illnesses can be considered a primary indirect measure of the incidence of these illnesses during the first years of life. However, mortality is significantly linked with factors associated with the severity of the episodes and with access to and use of available treatments to halt the disease and prevent it from becoming fatal.

Studies on the incidence of respiratory illnesses in early childhood lead to the conclusion that these are the most common causes of deteriorating health during the first five years of life. ${ }^{9-13}$ It is estimated that during this period, children suffer between four and eight episodes of respiratory infections. ${ }^{14}$ Episodes are more frequent in urban areas than in rural areas (six to eight episodes versus four to six episodes annually).

The frequency of these illnesses is associated to a great extent with the airborne transmission of the germs that produce them, both viruses and bacteria, and with the fact that children under five spend most of their time in enclosed spaces accompanied by adults or other children, which fosters the transmission of respiratory infections. $15-20$

To this average incidence of respiratory illnesses should be added other factors that come together to cause episodes to be more frequent, last longer, and be more severe. Particularly important are factors associated with greater irritation of the respiratory mucous membrane, which contribute to the colonization of that membrane by viruses or bacteria. Of these factors, the ones most frequently associated with respiratory infections, or with their severity, are air pollutants in the home, particularly smoke from cigarettes or from kitchens or stoves that use solid fuels for combustion. 17,20-22

Other risk factors are also related to the greater frequency, severity, or duration of respiratory illness in early childhood. Of particular note are malnutrition and the absence of breastfeeding. 15,17,20,23-26
Malnutrition lowers the body's defenses and puts it at greater risk of colonization by bacterial or viral agents that cause respiratory infections. As a result, episodes of these diseases are more serious and last longer. For its part, the lack or short duration of breastfeeding deprives children of the natural defenses transmitted from mother to child through breast milk. For this reason, children who are not exclusively breastfed are more susceptible to respiratory infections, and there is a greater risk that episodes of such illnesses will be more serious and last longer.

\section{Characteristics of care for children under five with respiratory illness}

In addition to the epidemiological conditions that determine the extent of the risk of young children contracting respiratory illnesses, as well as other factors such as nutritional status and breastfeeding practices, the care given to children once they have fallen ill is also critically important. $27-30$

Five aspects of care greatly influence the course and outcome of respiratory illness: parents' perception of the disease; patterns and habits of care administered to child during the illness; the level of concern in terms of the decision to seek assistance outside the home; the manner in which that outside care is sought; and the extent to which the recommendations regarding care are followed.

Parents' or caregivers' perceptions of the illness can be different. To some, symptoms of respiratory disease in their children are common and do not arouse particular concern. 31,32 This occurs most frequently if the child habitually has a cold or symptoms such as a cough or a runny nose. If the child is not perceived as ill, the care that he or she receives will be no different than usual. In the event of respiratory illness, this circumstance will be pivotal, since the lack of special care during episodes can cause the problem to become more persistent or even worsen.

When children suffer from respiratory illness even when the illness is not serious - they are less interested in eating or drinking. Less eating contributes to a deterioration in their nutritional status, and less liquid intake diminishes hydration of the respiratory secretions that serve as a vital defense mechanism for eliminating germs from the organism and warding off their colonization.

Respiratory illness exacerbates a child's inadequate nutritional status, while malnutrition in turn makes the respiratory episode worse or prolongs it. When families do not perceive the illness, children are given the customary care, and as a result, are not 
encouraged to eat more or drink more fluids.

In contrast, once the child's parents or caregivers perceive the illness and recognize it as such, their response can be a determining factor. This behavioral response basically includes the care administered to the sick child at home; how the level of concern relates to the decision to seek care outside of the home; the manner in which that care outside the home is sought; and the extent to which the care recommendations given to the parents are followed.

Care of the child in the home once the parents perceive that he or she is sick implies behavioral changes that can either help the child recover or make the problem worse.31,32 In some instances, parents reduce feeding or eliminate certain foods during the illness, apply ointments, offer herbal teas, administer drugs, etc. Their actions can be detrimental in some cases - for example, when they decide to reduce feeding or eliminate certain foods that are important energy sources for the child's recovery, or if the drugs or herbal teas administered are deleterious to the child's health.

Such actions also can delay care-seeking and, if treatment is required, make the illness worse and put the child's life in danger.

The level of concern of the child's parents or caregivers determines when they decide that the illness requires care that they are not capable of providing.30,32-38 The criteria employed by parents to identify this moment are different, as are the symptoms which they base the decision that the child needs care outside the home.

A low level of concern is generally associated with delays in utilizing the available health services, and, in cases where the illness progresses rapidly, with greater risk of the child dying at home. The delay in seeking help allows the illness to worsen to the critical stage, making treatment more prolonged and difficult, requiring more complex interventions, and increasing the risk of complications and sequelae (such as neurological sequelae that can follow septicemia or meningitis that begins in the lungs).

The manner in which outside care is sought also is important, because once parents have decided that the child's illness warrants outside care, they have different options at their disposal. These include traditional healers, drug retailers, or community or institutional health workers. $34,36,37,39,40$ Depending on the type of care sought, the family's initial contact for assistance outside the home can lead to the use of traditional methods to treat the illness and not necessarily to treatment by health services.

In other cases, the initial outside contact to treat the child's illness is drug retailers that are not always pharmacists, and from whom the families obtain medicines that they consider beneficial for treatment. The use of drugs without a prescription from health workers exposes the child to unnecessary or even detrimental drugs (such as cough syrups), or to inappropriate antibiotics, with the consequent risk of contributing to bacterial resistance to these drugs.

Finally, the extent to which recommendations for care are followed is also critical. Even when families seek early assistance from trained health workers, they often fail to follow the treatment as prescribed. 41,42 This can result in the child not receiving the quantities of drugs necessary to cure the illness, which makes the illness worse, requiring additional treatment. In other cases, although the illness may not worsen and the child recovers, inadequate administration of drugs can have other detrimental effects. This scenario is of particular concern in the case of antibiotics, which are sometimes administered in lower doses than required, or with incorrect intervals between doses, or for less time than the prescription indicates-all of which can contribute to the emergence of bacterial resistance.

\section{Bacterial resistance to antibiotics: an additional problem}

At least $30 \%$ of all hospitalized patients currently receive one or more cycles of antibiotic therapy, and these compounds have cured millions of infections that could otherwise have been fatal. At the same time, however, the compounds are among the products most misused by practicing physicians and have even been abused. A result of the widespread use of antibiotics has been the appearance of pathogenic microorganisms resistant to them. This in turn has been the springboard for the ever-growing need for newer drugs, which have substantially contributed to the spiraling costs of medical care. 43

Although some of the factors that contribute to the appearance of resistant bacteria are beyond human control, others are not.7,44 The presence of antibiotics, which enables resistant bacteria to proliferate, is the most controllable factor.

In general, the emergence of resistant bacteria has coincided with the widespread use of antibiotics and is due to the frequency with which the resistant bacteria come into contact with these drugs. Antibiotics have thus played a key role in inadvertently selecting strains of resistant bacteria 45 that can reproduce in greater quantity once the sensitive bacteria are destroyed by the antimicrobial treatment. This has increased the levels of bacterial resistance. $46-48$ 
Sensitivity of pneumococcus to penicillin in Latin America and the Caribbean. Results of surveillance of resistance, 1994-1998.

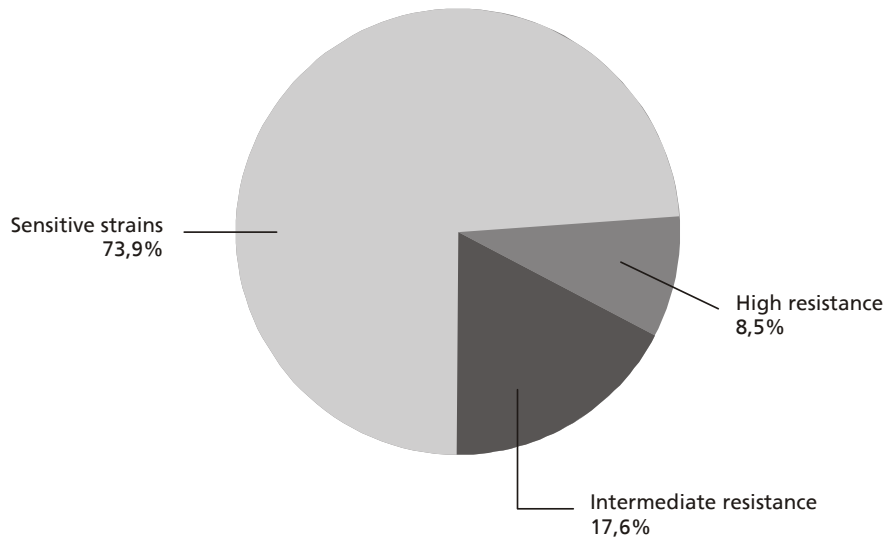

Source: Benguigui Y, Di Fabio JL. Vigilancia epidemiológica del Streptococcus pneumoniae en niños de América Latina. Bol Pneum Sanit 1998; 6 (1).

Figure 2

Levels of resistance of Streptococcus pneumoniae to penicillin in selected countries of Latin America. PAHO (Pan American Health Organizatopm), WHO (World Health Organization), SIREVA (Regional Vaccination System); $1994-1999$.

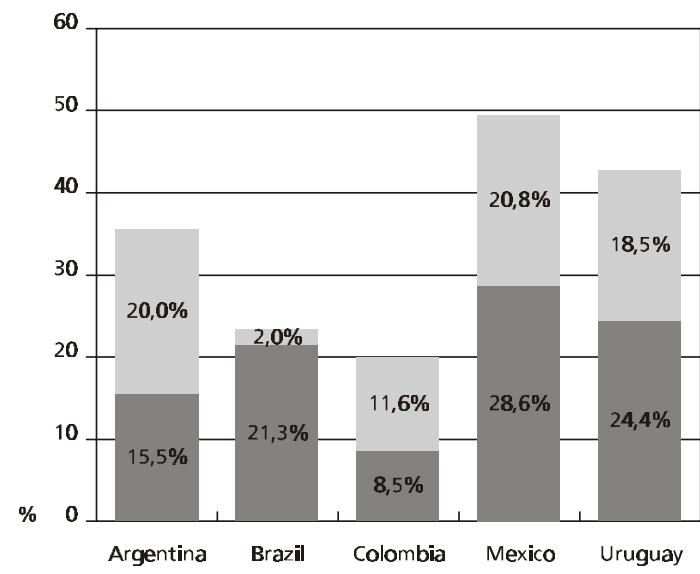
Intermediate practice is particularly dangerous among low-income groups. In order to save money, many people do not use the health services and therefore obtain only a fraction of the treatment necessary.

The Region of the Americas has high levels of bacterial resistance to antibiotics, particularly in certain countries.8,56-58 Streptococcus pneumoniae resistance to penicillin is $26,1 \%$ on average. This figure includes $8,5 \%$ regarded as a high level of resistance and $17,6 \%$ as intermediate resistance (Figure 1). Comparing countries (Figure 2), the figures range from $20,1 \%$ in Colombia to $49,4 \%$ in Mexico, according to a study conducted by Regional Vaccination System (SIREVA) during the period 1994 - 1999. Levels of high resistance ranged from $2 \%$ in Brazil to $20,8 \%$ in Mexico, and levels of intermediate resistance from $8,5 \%$ in Colombia to $28,6 \%$ in Mexico. 


\section{Alternatives for control}

Since respiratory diseases are a major cause of mortality and morbidity during early childhood, controlling them has been a priority for countries. Efforts have been directed toward prevention as well as early diagnosis and effective case management.

Preventive interventions are based on the possibility of having vaccines available that facilitate the prevention of ARI episodes, particularly for serious respiratory illnesses such as pneumonia that are the cause of most deaths. 59-61 Early diagnosis and effective treatment are based on the establishment of standard criteria that, when applied by primary care health workers, systematize treatment and case management in a manner that ensures the highest quality of care. These criteria also include educational content for parents and the community to ensure appropriate levels of concern and early consultation when there is an illness, as well as to promote care for children that reduces the risk and worsening of illness and fosters healthy growth and development.

\section{Vaccines}

Various studies have recognized the effectiveness of the current vaccines against Haemophilus influenzae and Streptococcus pneumoniae as a means of reducing the incidence of diseases of the respiratory tract in early childhood. The incidence of illnesses caused by Haemophilus influenzae - among them meningitis, pneumonia, and otitis - has been reduced in numerous countries with the administration of the vaccine.62-64 Similar studies are being published on the impact of vaccination against pneumococcus on the incidence of invasive disease caused by this bacterium. ${ }^{65-68}$

It should be noted that the results discussed in the previous paragraph generally correspond to developed countries, since the use of the Haemophilus influenzae vaccine in developing countries has been more recent. ${ }^{69}$ Use of the vaccine against Streptococcus pneumoniae is affected by the distribution of the serotypes of this bacterium most prevalent in each country. 70 The available vaccines initially covered the most common serotypes of Streptococcus pneumoniae found in the Northern hemisphere. However, the vaccines were rather ineffective for the developing countries of the Americas, where there is a high prevalence of serotypes not included in the vaccine.

In addition, the immunogenic strength of the initial vaccines was not high enough for children under two, who constitute one of the groups at highest risk and require the greatest protection. 71

At present, various types of vaccines against Streptococcus pneumoniae are being tested. These vaccines are highly immunogenic for children under two and combine different serotypes of the bacterium, making their use in developing countries potentially feasible.72-74 These advances have been accompanied by research that has allowed for a better description of the epidemiological distribution of the Streptococcus pneumoniae serotypes in the countries of the Americas, $56,58,70$ opening up short-term prospects for the incorporation of vaccines to prevent invasive diseases caused by this bacterium.

\section{Standardized case management}

The implementation of standard case management of early childhood respiratory illnesses is directed towards the early detection of cases by the family and the health services and towards improving the criteria for the management and treatment of cases once they are detected.

Standard case management (SCM) of acute respiratory infections was the first strategy disseminated regionally by the Pan American Health Organization (PAHO). It represented an important advance in systematizing the criteria for the evaluation, classification, and treatment of childhood respiratory illnesses on the basis of the available scientific information. 5

Application of the SCM/ARI strategy improved the management of acute respiratory illnesses at the primary care level.75,76 Evaluations in the countries showed the strategy's impact in terms of reducing the unnecessary use of antibiotics, 77,78 diminishing the frequency of complications from respiratory illnesses (particularly secondary pleural effusion to pneumonia), 78,79 and rationalizing the use of chest $\mathrm{x}$-rays as a tool for diagnosis. 77,80

The use of the strategy was restricted in practice to care of children under five whose symptoms met the criteria (cough or difficult breathing). Thus, children brought to health services for other reasons but had related respiratory problems did not benefit from the strategy. Opportunities for the early detection of respiratory illnesses were therefore missed because parents did not identify the early signs of disease.

Integrated Management of Childhood Illness, the principal intervention currently promoted by PAHO for improving child health, addresses the problem by integrating the specific strategies for the management of illness into a single approach. 81

IMCI involves a series of steps that must be followed whenever there is contact with a child under five. It permits the detection of any sign of illness, 
even though that illness might not be the principal reason for the consultation. The IMCI strategy also systematically includes disease prevention and health promotion activities, in this way turning any and all contact with a child under five into an opportunity for preventing disease and promoting healthy habits for growth and development during the first years of life.

Control of respiratory illness in children is thus one of the main components of the IMCI strategy. Application of the strategy makes it possible to identify all children with any sign of respiratory infection, evaluate them, and classify them in terms of the severity of the illness and the treatment required. It also allows for differentiating between children who require hospitalization, those who need antimicrobial treatment, and those who can be treated at home with measures to relieve their symptoms.

Application of the IMCI strategy has improved the detection of respiratory problems, since it involves checking for any symptoms of these illnesses in all children examined, rather than only in those whose parents mention respiratory illness as the reason for the consultation. Applying the criteria for evaluation, classification, and treatment in the IMCI strategy has made it possible to rationalize the use of diagnostic resources, reduce the use of antibiotics in cases with symptoms of pneumonia, and improve parents' knowledge about adequate care of children in the home and about the early warning signs indicating the need to seek assistance outside the home.

Initial evaluations of the IMCI strategy $82-85$ have demonstrated its importance in improving the quali- ty of care provided by primary health services.

Application of the IMCI strategy has been particularly important in fostering the appropriate use of antibiotics in managing ARI cases in children under five. A study in Santa Fe, Argentina ${ }^{86}$ shows that health services with staff trained in the IMCI strategy are much less likely to over-prescribe antibiotics for ARI treatment than are services without such trained staff, where the relative risk of over-prescribing antibiotics was 3,05, with a $\mathrm{p}<0,001$. Other studies in Latin American countries 87 have also shown a reduction in the unnecessary use of antibiotics for ARI treatment when the IMCI strategy is applied.

Reducing the unnecessary use of antibiotics is an important direct contribution of the IMCI strategy to containing bacterial resistance, particularly if one takes into account that most health services over-use antibiotics for ARI treatment. 88

The available data from the countries show an increase in the rate of decline in mortality from respiratory illness since the implementation of the IMCI strategy (Figure 3). Preliminary surveys that compare areas with high IMCI coverage with areas where the strategy has yet to be implemented show a significant difference in the rate of decline in mortality from respiratory illness (Figure 4).

Based on these findings, implementation and strengthening of the IMCI strategy for health services and communities is currently the principal intervention for the control of respiratory illness as a public health problem.

Figure 3

Total mortality trends and trends for acute respiratory infections in children under five years of age in 18 countries of the Americas, 1975-2000. Rates $₹$ 100.000 Inhabitants and percentage decline every five years between 1975 and 2000.

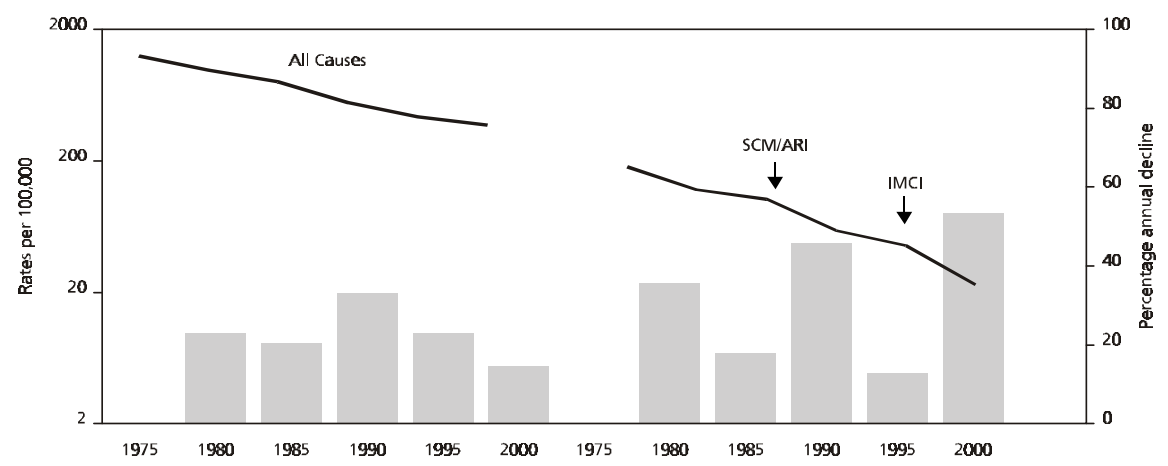

$A R I=$ Acute respiratory infections; SMC = Standard case management; IMCI = Integrated Management of Childhood IIIness Source: Special program for health analysis (SHA), Program on Communicable Diseases, IMCI (Integrated Management of Childhood Illness). Regional IMCI (HCT/IMCI). PAHO (Pan American Health Organization), WHO (World Health Organization); 2002. 
Decline in mortality from causes addressed by the IMCI (Integrated Management of Childhood IIness) strategy in departments in Peru, 1996-2000. Comparison between departments with and without IMCI.

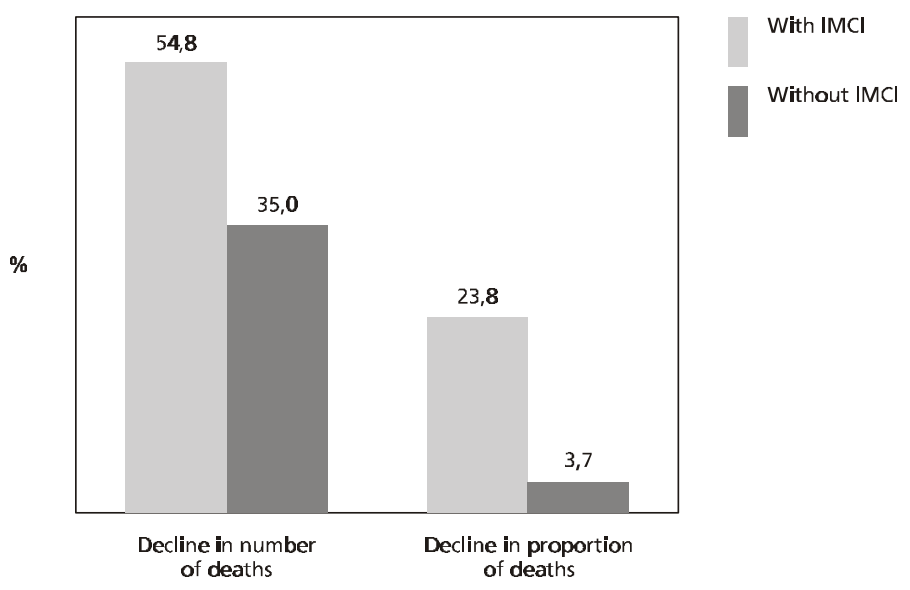

Source: Regional IMIC (Integrated Management of Childhood Ilness) database. Program on Communicable Diseases. Division of Disease Prevention and ControL (HCT/HCP). PAHO (Pan American Health Organization), WHO (World Health Organization); 2002.

\section{Outlook}

Implementation of the IMCI strategy has helped to accelerate the decline in mortality from respiratory illness and reinforce the benefits shown by the SCM/ARI strategy in terms of improving the quality of health care for children with respiratory illness, both in the home and in the health services. Although the development and administration of vaccines helps to prevent the most serious respiratory infections, vaccines will have an ever-greater impact once they cover a larger population. Incorporating these vaccines into the IMCI strategy - as they have already been incorporated into the Expanded Program on Immunization - will help to attain higher coverage levels. Current efforts to strengthen implementation of IMCI and its expansion in communities thus will lay the groundwork for a steady decline in mortality from respiratory infections.

In this way, IMCI becomes the most efficient intervention to prevent and control respiratory infections in children, with the potential to accelerate the decline in mortality from these causes and give families access to quality care for these illnesses.

\section{References}

1. Jellliffe D. Pediatrics. In: King M, editor. Medical care in developing countries. Nairobi: Oxford University; 1966. Chapter 13.

2. OPS (Organización Panamericana de la Salud), OMS (Organización Mundial de la Salud). La salud en las Américas. Washington, DC; 2002. p. 275-8. (Publicación Científica, 587).

3. PAHO (Pan American Health Organization). Health statistics from the Americas. Washington, DC; 1998. p. 14150. (Scientific Publication, 567).

4. Salvatierra-González R, Benguigui Y. Resistencia antimicrobiana en las Américas: magnitud del problema y su contención. Washington, DC: Organización Panamericana de la Salud; 2000. (OPS/HCP/HCT/163/2000).

5. OPS (Organización Panamericana de la Salud). Atención del niño con infección respiratoria aguda. Washington, DC; 1992. (Serie PALTEX para técnicos medios y auxiliares, 21)

6. OPS (Organización Panamericana de la Salud). Atención integrada a las enfermedades prevalentes de la infancia: curso clínico. Washington, DC; 1995.

7. OPS (Organización Panamericana de la Salud), OMS (Organización Mundial de la Salud). La salud en las Américas. Washington, DC; 1998. p. 71-6. (Publicación Científica, 569).

8. Argentina. Ministério de Salud. Instituto Nacional de Enfermedades Respiratorias "Emilio Coni". Las enfermedades 
objeto de la estrategia AIEPI en Argentina: 1980-2000. Buenos Aires; 2000.

9. Tupasi TE, De Leon LE, Lupisan S, Torres CU, Leonor ZA, Sunicoma ES. Community based studies of acute respiratory tract infections in young children. Patterns of acute respiratory infection in children: a longitudinal study in a depressed community in Metro Manila. Rev Infect Dis 1990; 12 (Suppl 8): S940-9.

10. Nicaragua. Instituto Nacional de Estadísticas y Censos. Encuesta nicaragüense de demografía y salud 1998. Nicaragüa: Macro International; 1999. p.146-53.

11. Guatemala. Instituto Nacional de Estadísticas. Encuesta de salud materno infantil 1998-1999. Guatemala: Macro International; 1999. p. 110-15.

12. Bolivia. Instituto Nacional de Estadística. Encuesta nacional de demografía y salud 1998. Bolivia: Macro International; 1998. p. 149-55.

13. Reublica Dominicana. CESDEM (Centro de Estudios Sociales y Demográficos). Encuesta demográfica y de salud 1996. Santo Domingo: Macro International; 1997. p.13946.

14. Pio A. The magnitude of the problem of acute respiratory infections. In: Douglas, RM, Kirby-Eaton E, editors Acute respiratory infections in childhood: proceedings of an international workshop. Sydney: University of Adelaide; 1985.

15. Etiler N, Velipasaoglu S, Aktekin M. Incidence of acute respiratory infections and the relationship with some factors in infancy in Antalya, Turkey. Pediatr Infect 2002 44: 64-9.

16. Flores Hernandez S, Reyes Morales H, Perez Cuevas R, Guiscafre Gallardo H. The day care center as a risk factor for acute respiratory infections. Arch Med Res 1999; 30: 216-23.

17. Lopez Bravo IM, Sepulveda H, Valdes I. Acute respiratory illnesses in the first 18 months of life. Rev Panam Salud Publica 1997; 1: 9-17.

18. Costa Fuchs S, Cássia Maynart R, Ferreira da Costa L, Cardozo A, Schierholt R. Duration of day-care attendance and acute respiratory infection. Cad Saúde Publica 1996; 12: 291-96.

19. Koopman LP, Smit HA, Heijnen MLA, Wijga A, van Strien RT, Kerkhof M. Respiratory infections in infants: interaction of parental allergy, child care, and siblings the PIAMA Study. Pediatrics 2001; 108: 943-8.

20. Broor S, Pandey RM, Ghosh M, Maitreyi RS, Lodha R, Singhal T, Kabra SK. Risk factors for severe acute lower respiratory tract infection in under-five children. Indian Pediatr 2001; 38: 1361-9.

21. Ezzati M, Kammen DM. Indoor air pollution from biomass combustion and acute respiratory infections in Kenya: an exposure-response study. Lancet 2001; 358: 619-24.

22. Smith KR, Samet JM, Romieu I, Bruce N. Indoor air pollution in developing countries and acute lower respiratory infections in children. Thorax 2000; 55: 518-32.

23. Arifeen S, Black RE, Antelman G, Baqui A, Caulfield L, Becker S. Exclusive breastfeeding reduces acute respiratory infection and diarrhea deaths among infants in Dhaka Slums. Pediatrics 2001; 108: E67.

24. López-Alarcón M, Villalpando S, Fajardo A. Breast-feeding lowers the frequency and duration of acute respiratory infection and diarrhea in infants under six months of age. J Nutr 1997; 127: 436-43.
25. Buñuel Álvarez JC, Vila Pablos C, Puig Congost, M, Díez García S, Corral Tomàs A, Pérez Oliveras M. Aten Primaria 2002; 31: 268-277.

26. Tupasi TE, de Leon LE, Lupisan S, Torres CU, Leonor ZA, Sunico ES. Patterns of acute respiratory tract infection in children: a longitudinal study in a depressed community in Metro Manila. Rev Infect Dis 1990; 2 (Suppl 8): S940-9.

27. Martinez H, Suriano K, Ryan GW, Pelto GH. Ethnography of acute respiratory infections in a rural zone of Mexican highlands. Salud Publica Mex 1997; 39: 207-16.

28. Saenz de Tejada S. Management of acute respiratory infections in a Kaqchiquel community in Guatemala. Rev Panam Salud Publica 1997; 1: 259-65.

29. Rashid SF, Hadi A, Afsana K, Begum SA. Acute respiratory infections in rural Bangladesh: cultural understandings, practices and the role of mothers and community health volunteers. Trop Med Int Health 2001; 6: 249-55.

30. Valdes Roque AI, Martinez Canalejo H. Educational level of mothers and their knowledge, attitude and practices concerning respiratory infections of their children. Rev Panam Salud Publica 1999; 6: 400-7.

31. Muhe L. Mothers' perceptions of signs and symptoms of acute respiratory infections in their children and their assessment of severity in an urban community of Ethiopia. Ann Trop Paediatr 1996; 16: 129-35.

32. Iyun BF, Tomson G. Acute respiratory infections-mothers' perceptions of etiology and treatment in south-western Nigeria. Soc Sci Med 1996; 42: 437-45.

33. Gadomski AM, Aref GH, Hassanien F, el Ghandour S, elMougi M, Harrison LH, Khallaf N, Black RE. Caretaker recognition of respiratory signs in children: correlation with physical examination findings, $\mathrm{x}$-ray diagnosis and pulse oximetry. Int J Epidemiol 1993; 22: 1166-73.

34. Gálvez CA, Modeste N, Lee JW, Betancourt H, Wilkins RL. Peruvian mothers' knowledge and recognition of pneumonia in children under 5 years of age. Rev Panam Salud Publica 2002; 11: 99-108.

35. Mull DS, Mull JD, Kundi MZ, Anjum M. Mothers' perceptions of severe pneumonia in their own children: a controlled study in Pakistan. Soc Sci Med 1994; 38: 973-87.

36. Campbell H, Byass P, Greenwodd BM. Acute lower respiratory infections in Gambian children: maternal perception of illness. Ann Trop Paediatr 1990; 10: 45-51.

37. Gross GJ, Howard M. Mothers' decision-making processes regarding health care for their children. Public Health Nurs 2001; 18: 157-68.

38. Tarkka MT, Paunonen M, Laippala P. First-time mothers and child care when the child is 8 months old. J Adv Nurs 2000; 31: 20-6.

39. Teka T, Dagnew M. Health behaviour of rural mothers to acute respiratory infections in children in Gondar, Ethiopia. East Afr Med J 1995; 72: 623-5.

40. Saini NK, Gaur DR, Saini V, Lal S. Acute respiratory infections in children: a study of knowledge and practices of mothers in rural Haryana. J Commun Dis 1992; 24 : 75-7.

41. Santos MARC, Dutra MVP, Sant'Anna CC, Bonfim DC. Cumplimiento de la antibioticoterapia en niños con neumonía. In: Benguigui Y, editor. Investigaciones operativas sobre el control de las infecciones respiratorias agudas (IRA) en Brasil. Washington, DC: Organización Panamericana de la Salud; 1999. p. 145-163. (Serie 
HCT/AIEPI-2.E)

42. Reyes H, Guiscafre H, Muñoz O, Perez-Cuevas R, Martinez H, Gutitierrez G. Antibiotic noncompliance and waste in upper respiratory infections and acute diarrhea. J Clin Epidemiol 1997; 50: 1297-1304.

43. Chambers HF, Sande MA. Fármacos antimicrobianos: consideraciones generales. In: Hardman JG, Limbird LE, Molinoff PB, Ruddon RW, Goodman-Gilman A. Las bases farmacológicas de la terapéutica. 9.ed. Mexico: McGraw-Hill; 1996. p. 1095-121.

44. Larsson M, Kronvall G, Chuc NT, Karlsson I, Lager F, Hanh HD, Tomson G, Falkenberg T. Antibiotic medication and bacterial resistance to antibiotics: a survey of children in a Vietnamese community. Trop Med Int Health 2000; 5: 711-21.

45. Varon E, Levy C, De La Rocque F, Boucherat M, Deforche D, Podglajen I, Navel M, Cohen R. Impact of antimicrobial therapy on nasopharyngeal carriage of Streptococcus pneumoniae, Haemophilus influenzae, and Branhamella catarrhalis in children with respiratory tract infections. Clin Infect Dis 2000; 31: 477-81.

46. Ehrhardt AF, Russo R. Clinical resistance encountered in the respiratory surveillance program (RESP) study: a review of the implications for the treatment of communityacquired respiratory tract infections. Am J Med 2001; 17; 111 (Suppl 9A): 30S-35S [Discussion].

47. Schito GC, Debbia EA, Marchese A. The evolving threat of antibiotic resistance in Europe: new data from the Alexander Project. J Antimicrob Chemother 2000; 46 (Suppl 1): 3-9.

48. Hoban DJ, Doern GV, Fluit AC, Roussel-Delvallez M, Jones RN. Worldwide prevalence of antimicrobial resistance in Streptococcus pneumoniae, Haemophilus influenzae, and Moraxella catarrhalis in the SENTRY Antimicrobial Surveillance Program, 1997-1999. Clin Infect Dis 2001; 32 (Suppl 2): S81-93.

49. Le Saux N, Bjornson C, Pitters C. Antimicrobial use in febrile children diagnosed with respiratory tract illness in an emergency department. Pediatr Infect Dis J 1999; 18: 1078-80.

50. Raherison C, Peray P, Poirier R, Romand P, Grignet JP, Arsac P, Taytard A, Daures JP. Management of lower respiratory tract infections by French general practitioners: the AIR II study. Analyse infections respiratoires. Eur Respir J 2002; 19: 314-9.

51. McIsaac WJ, Goel V, To T, Low DE. The validity of a sore throat score in family practice. CMAJ 2000; 163: 811-5.

52. Murray S, Del Mar C, O'Rourke P. Predictors of an antibiotic prescription by GPs for respiratory tract infections: a pilot. Fam Pract 2000; 17: 386-8.

53. Bojalil R, Guiscafre H, Espinosa P, Martinez H, Palafox M, Romero G, Gutierrez G. The quality of private and public primary health care management of children with diarrhoea and acute respiratory infections in Tlaxcala, Mexico. Health Policy Plan 1998; 13: 323-31.

54. Chuc NT, Larsson M, Falkenberg T, Do NT, Binh NT, Tomson GB. Management of childhood acute respiratory infections at private pharmacies in Vietnam. Ann Pharmacother 2001; 35: 1283-8.

55. Kroeger A, Ochoa H, Arana B, Diaz A, Rizzo N, Flores W. Inadequate drug advice in the pharmacies of Guatemala and Mexico: the scale of the problem and explanatory factors. Ann Trop Med Parasitol 2001; 95: 605-16.
56. Kertesz DA, Di Fabio JL, de Cunto Brandileone MC, Castaneda E, Echaniz-Aviles G, Heitmann I, Homma A, Hortal M, Lovgren M, Ruvinsky RO, Talbot JA, Weekes J, Spika JS. Invasive Streptococcus pneumoniae infection in Latin American children: results of the Pan American Health Organization surveillance study. Clin Infect Dis 1998; 26: 1355-61.

57. Hortal M, Lovgren M, de la Hoz F, Agudelo CI, Brandileone MC, Camou T, Casagrande S, Castaneda E, Corso A, Echaniz G, Hormazabal JC, Pace J, Palacio R, Perez-Giffoni G, Ruvinsky R, Di Fabio JL. Antibiotic resistance in Streptococcus pneumoniae in six Latin American countries: 1993-1999 surveillance. Microb Drug Resist 2001; 7: 391-401.

58. Di Fabio JL, Castaneda E, Agudelo CI, De La Hoz F, Hortal M, Camou T, Echaniz-Aviles G, Noemi M, Barajas C, Heitmann I, Hormazabal JC, Brandileone MC, Dias Vieira VS, Regueira M, Ruvinski R, Corso A, Lovgren M, Talbot JA, De Quadros C. Evolution of Streptococcus pneumoniae serotypes and penicillin susceptibility in Latin America: 1993 to 1999. Pediatr Infect Dis J 2001; 20: 959-67.

59. Obaro S, Adegbola R. The pneumococcus: carriage, disease and conjugate vaccines. J Med Microbiol 2002; 51: 98 104.

60. Overturf GD. Prevention of pneumococcal infections, including the use of pneumococcal conjugate and polysaccharide vaccines and antibiotic prophylaxis. Pediatrics 2000; 106 Pt 1: 367-76.

61. WHO (World Health Organization). Pneumococcal vaccines: position paper. Can Commun Dis Rep 1999; 25: 150-1.

62. Wenger JD. Epidemiology of Haemophilus influenzae type $\mathrm{b}$ disease and impact of Haemophilus influenzae type $\mathrm{b}$ conjugate vaccines in the United States and Canada. Pediatr Infect Dis J 1998; 17 Suppl: S132-6.

63. Herceg A. The decline of Haemophilus influenzae type $b$ disease in Australia. Commun Dis Intell 1997; 26: 1736.

64. Diez-Domingo J, Pereiro I, Morant A, Gimeno C, SanMartin M, Gonzalez A. Impact of non-routine vaccination on the incidence of invasive Haemophilus influenzae type $\mathrm{b}$ (Hib) disease: experience in the autonomous region of Valencia, Spain. J Infect 2001; 42: 257-60.

65. Whitney CG, Pickering LK. The potential of pneumococcal conjugate vaccines for children. Pediatr Infect Dis J 2002; 21: 961-70.

66. Butler JC, Shapiro ED, Carlone GM. Pneumococcal vaccines: history, current status, and future directions. Am J Med 1999; 26 (Supp 1A): 69S-76S.

67. Lee LH, Lee CJ, Frasch CE. Development and evaluation of pneumococcal conjugate vaccines: clinical trials and control tests. Crit Rev Microbiol 2002; 28: 27-41.

68. Whitney CG, Pickering LK. The potential of pneumococcal conjugate vaccines for children. Pediatr Infect Dis J 2002; 21: 961-70.

69. Dickinson FO, Perez AE, Galindo MA, Quintana I. Impact of vaccination against Haemophilus influenzae type b in Cuba. Rev Panam Salud Publica 2001; 10: 169-73.

70. Hortal M, Ruvinsky R, Rossi A, Agudelo CI, Castaneda E, Brandileone C, Camou T, Palacio R, Echaniz G, Di Fabio JL. Impact of Streptococcus pneumoniae on pneumonia in Latin American children. Rev Panam Salud Publica 2000; 8: 185-95. 
71. Asociación Española de Pediatria.iComité Asesor de Vacunas. La enfermedad neumocócica y su prevención. Vacuna neumocócica conjugada heptavalente. An Espan Pediatr 2002; 56: 79-90.

72. Obaro SK. The new pneumococcal vaccine. Clin Microbiol Infect 2002; 8: 623-33.

73. Murray D, Jackson C. A conjugate vaccine for the prevention of pediatric pneumococcal disease. Mil Med 2002; 167: 671-7.

74. Horwood F, Macfarlane J. Pneumococcal and influenza vaccination: current situation and future prospects. Tho$\operatorname{rax} 2002 ; 57$ (Suppl 2): II24-30.

75. Cunha AJ. Management of acute respiratory infections in children: evaluation in Rio de Janeiro health care facilities. Cad Saude Publica 2002; 18: 55-61.

76. Chatkin de Oliveira M. Evaluación del impacto de las acciones de control de las infecciones respiratorias agudas en Pelotas, RS, Brasil: una investigación operativa. In: Benguigui Y, editor. Investigaciones operativas sobre el control de las infecciones respiratorias agudas (IRA) en Brasil. Washington: Organización Panamericana de la Salud; 1999. 213-21. (Serie HCT/AIEPI-2.E)

77. Razón R, Ponce J, Blanco A, Ramos LT, González M, Gran M. Impacto de las acciones de control de las infecciones respiratorias agudas (IRA) en niños menores de 5 años en Cuba. In: Benguigui Y, Valenzuela C, editores. Investigaciones operativas sobre el control de las infecciones respiratorias agudas (IRA) en niños de América Latina y el Caribe. Washington, DC: Organzación Panamericana de la Salud; 1998. p. 183-208. (Serie HCT/AIEPI-3.E).

78. Qazi SA, Rehman GN, Khan MA. Standard management of acute respiratory infections in a children's hospital in Pakistan: impact on antibiotic use and case fatality. Bull World Health Organ 1996; 74: 501-7.

79. Torres Díaz M, Fuenmayor T, Márquez MPE. Impacto del programa de IRA en la mortalidad hospitalaria del servicio de pediatría del hospital General del Sur, Maracaibo, Venezuela. In: Benguigui Y, Valenzuela C, editores. Investigaciones operativas sobre el control de las infecciones respiratorias agudas (IRA) en niños de América Latina y el Caribe. Washington, DC: Organización Panamericana de la Salud; 1998. p. 103-7. (Serie HCT/AIEPI-3.E).
80. Fernández JA. Impacto de las acciones de control de las IRA en el hospital "San José" de la ciudad Cañada de Gómez, provincia de Santa Fe, Argentina. In: In: Benguigui $\mathrm{Y}$, Valenzuela $\mathrm{C}$, editores. Investigaciones operativas sobre el control de las infecciones respiratorias agudas (IRA) en niños de América Latina y el Caribe. Washington, DC: Organización Panamericana de la Salud; 1998. p. 109-21. (Serie HCT/AIEPI-3.E).

81. Gove S, Tamburlini G, Molyneux E, Whitesell P., Campbell $\mathrm{H}$. Development and technical basis of simplified guidelines for emergency triage assessment and treatment in developing countries. WHO Integrated Management of Childhood Illness (IMCI) Referral Care Project. Arch Dis Child 1999; 81: 473 - 7.

82. Lambrechts, T., Bryce, J., and Orinda, V. Integrated management of childhood illness: a summary of first experiences. Bull World Health Organ 1999;77: 582-94.

83. Heiby, J.R. Quality improvement and the integrated management of childhood illness: lessons from developed countries. Jt Comm J Qual Improv 1998; 24: 264-79.

84. Shah, D., Sachdev, H.P. Evaluation of the WHO/UNICEF algorithm for integrated management of childhood illness between the age of two months to five years. Indian Pediatr 1999; 36: 767-77.

85. Gupta, R., Sachdev, H.P., and Shah, D. Evaluation of the WHO/UNICEF algorithm for integrated management of childhood illness between the ages of one week to two months. Indian Pediatr 2000; 37: 383-90.

86. Instituto Nacional de Enfermedades Respiratorias "Emilio Coni". Evaluación de resultados de la aplicación de la estrategia AIEPI en servicios de salud de Santa Fe, Argentina (forthcoming).

87. OPS (Organización Panamericana de la Salud). La AECI y el Ministerio de sanidad y consumo de españa apoyan la expansión de AIEPI. 2001; (5): 17-9.

88. Gonzalez Ochoa E, Armas Perez L, Bravo Gonzalez JR, Cabrales Escobar J, Rosales Corrales, R, Abreu Suarez G. Prescription of antibiotics for mild acute respiratory infections in children. Bull Pan Am Health Organ 1996; 30: 106-17.

Submitted on September 16, 2002

Final version resubmitted on November 18, 2002

Approved on January 10, 2003 